description, a potted history and notes on cultivation. The plants selected by Tyler Whittle and Christopher Cook have been arranged in order of their introduction to Europe, with the original text replaced by a new one, mixing botany, gardening and historical chit-chat with quotations from Turner, Gerard, Parkinson, Curtis himself and other botanical classics.

InLib. primum Diofcoridis.

215

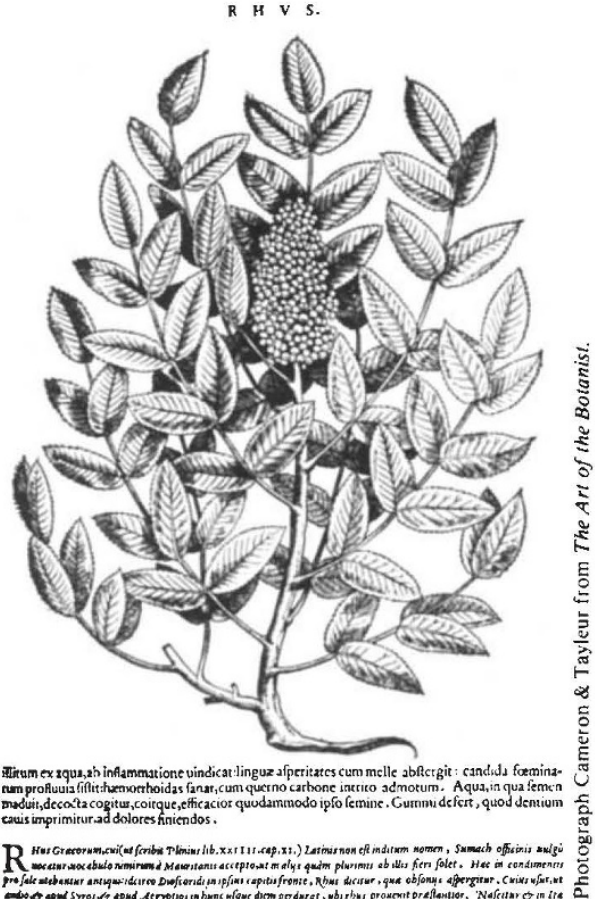

“'Rhus", possibly the stag's horn sumach (Rhu typhina). Woodcut from Commentarii in Sex Libros Pedacii Dioscoridis, 1565 edition, by Pierandrea Matthioli.

The arrangement echoes that of the Botanical Magazine itself, each plate facing its appropriate text. The plates are good copies of the originals, and the book is a very attractive production, making it even more of a pity that such a pleasant piece of printing is spoiled by extremely careless copy-editing and proof-reading. Misprints are numerous, perhaps the most comic being "naval wort" for navel-wort. Several personal names appear in variant forms; even Linnaeus's are given in the wrong order: Linnaeus was his family name, and he did not become von Linné until he was ennobled.

This selection of early Curtis plates will be welcomed by gardeners interested in the history of the plants they grow. It might even lead them to a full set of the Botanical Magazine itself, or perhaps to the dozen plates from recent issues sold as a calendar at Kew each year - a pleasant annual glimpse of some of the best of today's botanical illustration.

Sandra Raphael is Senior Editor (Natural History) in the Dictionary Department of Oxford University Press. She is currently working on a new edition of Wilfrid Blunt's The Art of Botanical Illustration.

\title{
... and of the garden at Cambridge
}

\section{Blanche Henrey}

The Shaping of Cambridge Botany: $A$ Short History of Whole-Plant Botany in Cambridge from the Time of Ray into the Present Century. By S.M. Walters. Pp.121. ISBN 0-521-23795-5. (Cambridge University Press: 1981.) £17.50, \$42.50.

THIS slim quarto volume was published to mark the 150th anniversary of an Act of Parliament, dated 30 March 1831, authorizing the acquisition of land from Trinity Hall for the development of a New Botanic Garden. By that time the eighteenth-century Walkerian Garden founded in 1762 had become too small, and, in the words of the Professor of Botany, J.S. Henslow, "utterly unsuited to the demands of modern science".

The book gives a brief and interesting history of the scientific study of botany in Cambridge; and the author, though not going very deeply into his subject, provides the botanist with a useful and handy source book. Moreover, at the present time when the study of garden history has such a wide appeal, a publication with special reference to the teaching, planning and research, carried on over the years in the garden at Cambridge, offers much of interest to the garden historian.

Dr Walters, at one time Curator of the Cambridge Herbarium and Lecturer in the Botany School, and now Director of the Garden, has written this book chiefly from material obtained from published works, from some unpublished manuscripts and from knowledge that he has acquired over many years of association with the University. It consists of a history of botanical and horticultural science in Cambridge from the seventeenth century, when John Ray established the tradition of herborizing, or plant hunting expeditions, until the establishment of specialized modern branches of botany, such as genetics and ecology, in the present century.

The eight chapters cover various stages in the development of the Garden and Cambridge botany. Details are given of the lives of the important figures in the history of the science and the part that some of these men played. Among them, from the time of Ray until 1825, are Richard Bradley, and John and Thomas Martyn, and from 1725 onwards, John Steven Henslow, Charles Cardale Babington, Sydney Vines, Richard Irwin Lynch, and Harry Marshall Ward and his successors.

A chronology at the end of the work, giving dates of historical events, lives of personalities, publications and so on, would have been a useful addition. In compensation, a feature of the book is the large number of illustrations -84 in all depicting title-pages, frontispieces, maps, portraits, plants and other subjects. There are also illustrations of specimens from
Ray's own herbarium, from Martyn's herbarium, and an illustration of an herbarium specimen Silena maritima made by James Donn. Furthermore, a number of figures of plants are reproduced from original drawings made specially for the work by Michael Hickey. Many of the figures occupy the wide margins of the book, enlivening the pages and creating a unity between text and illustrations. A coloured reproduction of Rosa "Cantabrigiensis" from a water-colour drawing by Graham Stuart Thomas, Gardens Consultant to the National Trust, makes a charming frontispiece.

Blanche Henrey is an Honorary Associate of the British Museum (Natural History), and author of British Botanical and Horticultural Literature (Oxford University Press, 1975).

\section{Britain in leaf}

\section{Alan Mitchell}

A SINGLE volume on trees cannot, unlike one on birds, extend its coverage to the Mediterranean shores without losing much of its use in British gardens. The Hamlyn Guide to Trees of Britain and Europe by C. Humphries, J.R. Press and D.A. Sutton (Hamlyn; hbk £5.95, pbk £3.95) is a good example. Of the total of 20 species of pears and eucalypts covered, 15 are not grown in Britain. To encompass these and some obscure southern oaks and maples, the authors have had to omit important trees like Low's and Nikko firs, and, worse, ignore all the cultivars of Lawson and Sawara cypresses which crowd our parks and gardens. The book, then, will be of most use in the field in southern Europe. It has a good, workable synoptic key, and excellent descriptions and illustrations of details, though the whole-tree drawings are seldom in the least helpful and a few are quite wrong.

Alan Fairhurst and Eric Soothill's Blandford Guide to Trees of the British Countryside (Blandford, f9.95) contains beautiful photographs of the bark, foliage, flowers and fruit of the 55 trees, 9 shrubs and ivy which are given full treatment, and of a few of the 86 trees and 18 shrubs more briefly described or just mentioned. This last, however, is quite pointless when so many common trees are omitted altogether. The marginal outline drawings are reasonably distinctive (but "Dutch elm"' is plainly English elm). The strength of this book, and exceptional feature, is the long lists of fungi and insects associated with each species, and of local names for the trees. The entries for timber uses and the general information are also good value. 